\title{
PROPOSITION FOR THE INTRODUCTION OF THE CONCEPT TELE- MATHESIS IN VIDEOCONFERENCING IN DISTANCE EDUCATION
}

Athanasios Kanellopoulos [tkgr1973@gmail.com], Maria Koutsouba [makouba@phed.uoa.gr], Yiannis Giossos [ygiossos@phed.uoa.gr], Hellenic Open University [http://www.eap.gr], Greece

\begin{abstract}
The development of technology and the widespread application of digital tools, such as teleconference (or videoconference), has led researchers to reflect on traditional theories and models of learning concerning Distance Education, as well as the formulation of new ones. The aim of this study is to propose the introduction of the concept tele-mathesis in Distance Learning, in order to describe the learning process by videoconferencing in Distance Education, which has features of an "embodied" and "integrated" way of learning. This is a theoretical study based on Illeris' Theory of "Integrated" Learning that has been adopted in Distance Learning, using elements of the Theory of Tele-proximity concerning learning by videoconferencing in Distance Education. According to the developed argumentation the importance of the senses, emotions and "techniques of the body" is revealed in both the educational and learning process by videoconferencing, in order to reduce the transactional distance between the teacher and the learner, as well as, to lead to a positive distance educational experience. Thus, the cognitive, emotional and social factors involved in "tele-mathesis", turn videoconferencing into an "embodied" and "integrated" way of learning. At the same time, it is showed that the empowerment of "tele-mathesis" requires appropriate planning and specific management methods. It is therefore proposed to introduce the term telemathesis in Distance Education so as to fully attribute this specific learning process of Distance Education.
\end{abstract}

\section{Abstract in Greek}

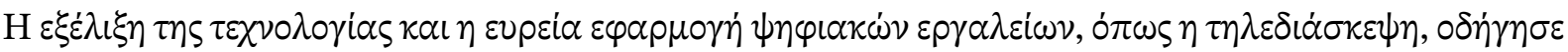

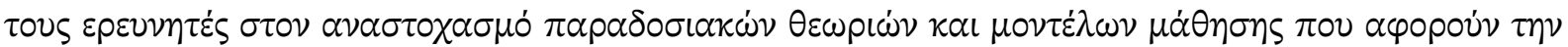

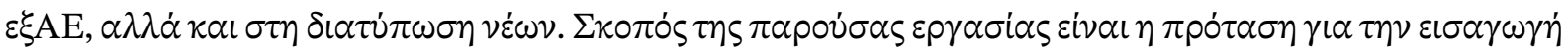

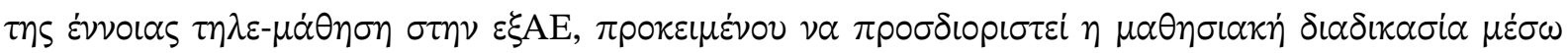

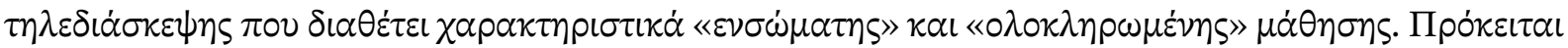

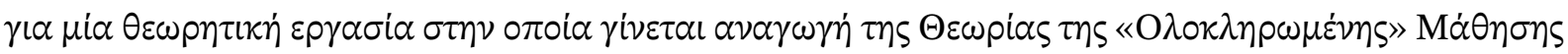

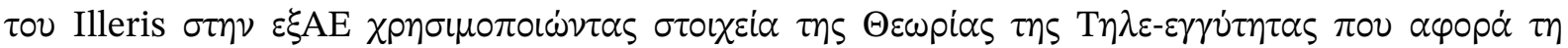

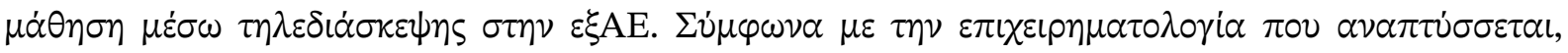

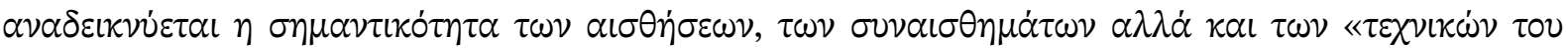

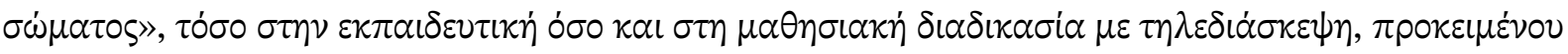

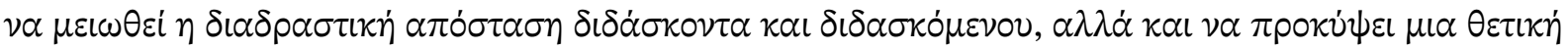

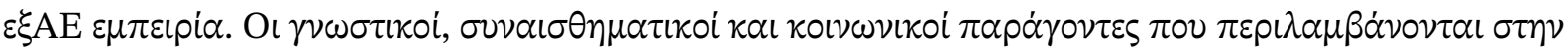

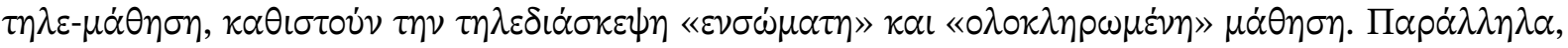




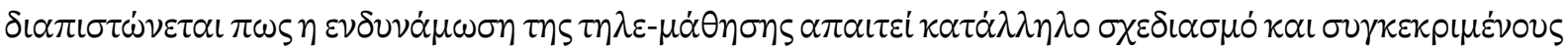

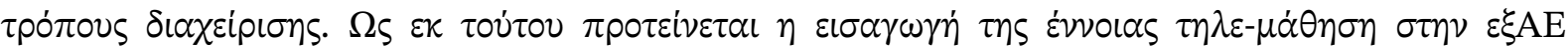

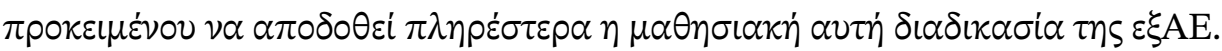

Keywords: Tele-Community of Inquiry Model, Theory of Tele-proximity, Theory of "Integrated" Learning, audiovisual learning, embodied learning

\section{Introduction}

Tabula rasa or Tabula inscripta? An interactive philosophical discussion about the nature of learning that started thousands of years ago but remains always timely since it is, even today, a research subject of many scientific fields dealing with learning and education generally. Since the era in which Aristotle was claiming that learning is based on experience and sensations (Papagiannidis, 2008), researchers now argue that learning is achieved through shifts of the perception that leads to change of behaviour, thinking and emotions (Illeris, 2016; Lachman, 1997; Rogers, 1999; Schunk, 2012). Various theories have been developed about learning, such as the Illeris' Theory of "Integrated" learning (Illeris, 2009; 2015; 2016) that places the learning process in a holistic perspective, highlighting the significant effects of cognitive, emotional and social interaction in the acquisition of knowledge.

Learning as a process is the same, regardless of how the learner is involved (Lionarakis, 2006) or whether there is a geographical distance between the teacher and the learner, as is the case in Distance Education. This is because learning is associated with the mental and interactive processes of human being and it is not about the educational method used (Illeris, 2016; Kanellopoulos \& Koutsouba, 2017). On this basis, it can be argued that already existed cognitive and social learning theories can be discussed in relation to distance learning.

Moreover, Information and Communication Technologies (ICT) in distance learning undoubtedly contributed to the enhancement of both teaching and learning in Distance Education (Mavroidis, Karatrantou, Koutsouba, Giossos, \& Papadakis, 2013). Videoconference, in fact, is one of the most widespread digital tools of Distance Education, as a basic media of communication between teacher and learner (Wu, Lin, \& Yang, 2013; Lionarakis, Papadimitriou, Hartofylaka, Aggeli, \& Tzilou, 2018). In videoconferencing, participants communicate and interact in real time, via video or audio, or both, using online technology to bridge the geographic distance among them (Mavroidis et al., 2013; Panagiotakopoulos, Tsiatsos, Lionarakis, \& Tzanakos, 2013; Wu et al., 2013; Anastasiadis et al., 2011; Anastasiadis et al., 2009; Gkousios \& Tzanavari, 2009). In fact, videoconferencing is a multi-media communication tool that can have educational implementation. Learning, through it, is influenced by audiovisual messages are transmitted (Kanellopoulos, Koutsouba, \& Giossos, 2020).

Community of Inquiry Model (Garrison, Anderson, \& Archer, 1999) with its three dimensions social, cognitive and teaching presence - that was adapted to the synchronous way of communication by Themeli and Bougia (2016) with the Theory of Tele-proximity, highlighting the importance of intimacy between participants and non-verbal communication messages (Mavroidis 
et al., 2013; Themeli \& Bougia, 2016; Wu et al., 2013) can been adopted in videoconferencing. At this point, it should be clarified that in this study the term videoconferencing also refers to the term teleconferencing.

Immediacy and intimacy are two features that enhance the social presence of participants in a Community of Inquiry contributing to the development of a positive learning climate (Mavroidis et al., 2013). Decoding non-verbal communication plays a key role in this (Themeli \& Bougia, 2016; Wu et al., 2013). Specifically, it highlights the contribution of the human body to the learning process through videoconferencing (Lakoff, 2012; Wilson \& Foglia, 2016). In any case, interaction is a key component of the learning process in Distance Learning (Hillman, Willis, \& Gunawardena, 1994; Moore, 1989) and can reduce the transactional distance between teacher and learner (and/or learning environment) as proposed by Moore (1993).

Discussion about the learning process and the quality of the educational process in Distance Education is ongoing, while videoconferencing has provoked intense research interest in the scientific field of Distance Learning (Kanellopoulos, 2019; Kanellopoulos \& Koutsouba, 2019). Nevertheless, videoconferencing has not been studied from a pedagogical point of view in Distance Learning (Kanellopoulos, 2019; Kanellopoulos \& Koutsouba, 2019), a learning process that is dynamic and complicated, has cognitive, emotional and social features, and is based on both audiovisual learning and embodied learning. That is why a new concept needs to be introduced.

The aim of this study is to propose the introduction of the concept tele-mathesis in Distance Learning, in order to define the learning process by videoconferencing in the Distance Education, which has features of an "embodied" and "integrated" way of learning. This is a theoretical study based on Illeris' Theory of "Integrated" Learning that has been adopted in Distance Learning, using elements of the Theory of Tele-proximity concerning learning by videoconferencing in Distance Education. In order to do so, the theoretical background of the concept tele-mathesis will be discussed and defined.

\section{The fundamental theoretical background of the concept tele-mathesis}

\section{Theory of Tele-proximity}

Community of Inquiry Model, one of the most used in the international literature of Distance Learning, although it contributes significantly to the scientific field of Distance Learning, was criticised whether it can be applied on synchronous ways of communication (Jézégou, 2010; Xin, 2012). The Theory of Tele-proximity responded to this critique. This theory emphasizes the social relationships among the members of an educational videoconference group. It interprets their way of interaction by likening the videoconferencing to a "theatrical scene" (Pentland, 2012; Themeli \& Bougia, 2016; Themelis, 2014). The learning process in Distance Education, through videoconferencing, is improved through the cultivation of immediacy and intimacy that leads to the reduction of the transactional distance (Themeli \& Bougia, 2016). The theory introduces the Tele-Community of Inquiry Model that includes the tele-cognitive, tele-teaching and tele-social presences (Themeli \& Bougia, 2016; Themelis, 2014) (Figure 1). 


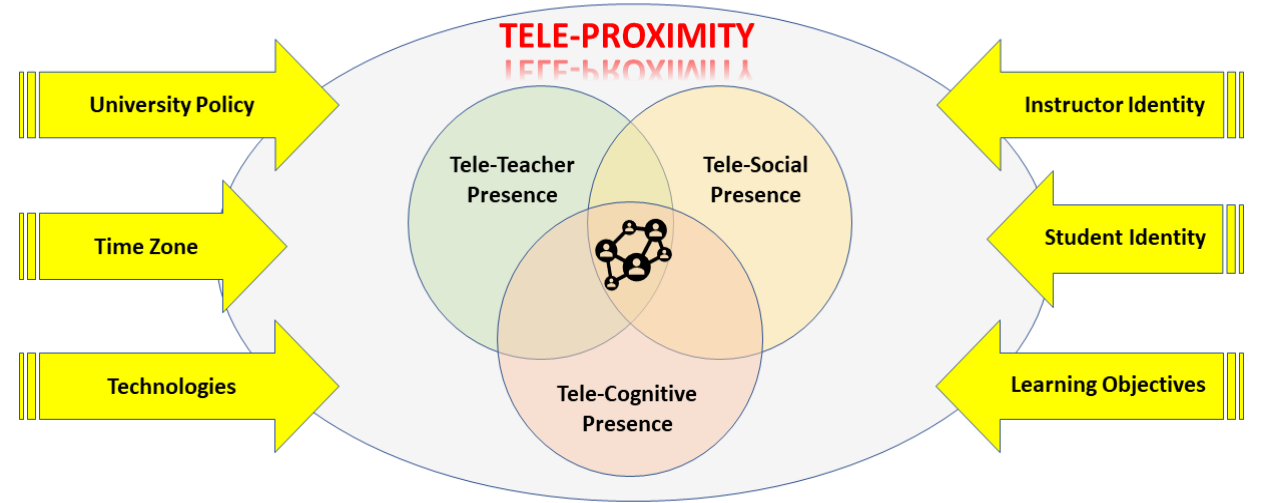

Figure 1. Theory of Tele-proximity. Adapted from Themeli and Bougia (2016; p.153, Fig. 1.1)

Though tele-presences of the Tele-Community of Inquiry Model are based on the presences of the Community of Inquiry Model, they have additional characteristics (Kanellopoulos et al., 2020) (Figure 2). According to the literature, the audiovisual messages transmitted by the participants during videoconferencing, affect the tele-presences (Iacoboni, 2009; Lakoff, 2012; Pentland, 2010, 2012; Sime \& Themelis, 2018; Themeli \& Bougia, 2016; Themelis, 2014; Wilson \& Foglia, 2016). Moreover, in videoconferencing the learning process is influenced by the technical problems that may arise, from the attitudes of the participants and from all those factors that influence the inperson learning process (Themelis, 2014; Armakolas \& Panagiotakopoulos, 2020).

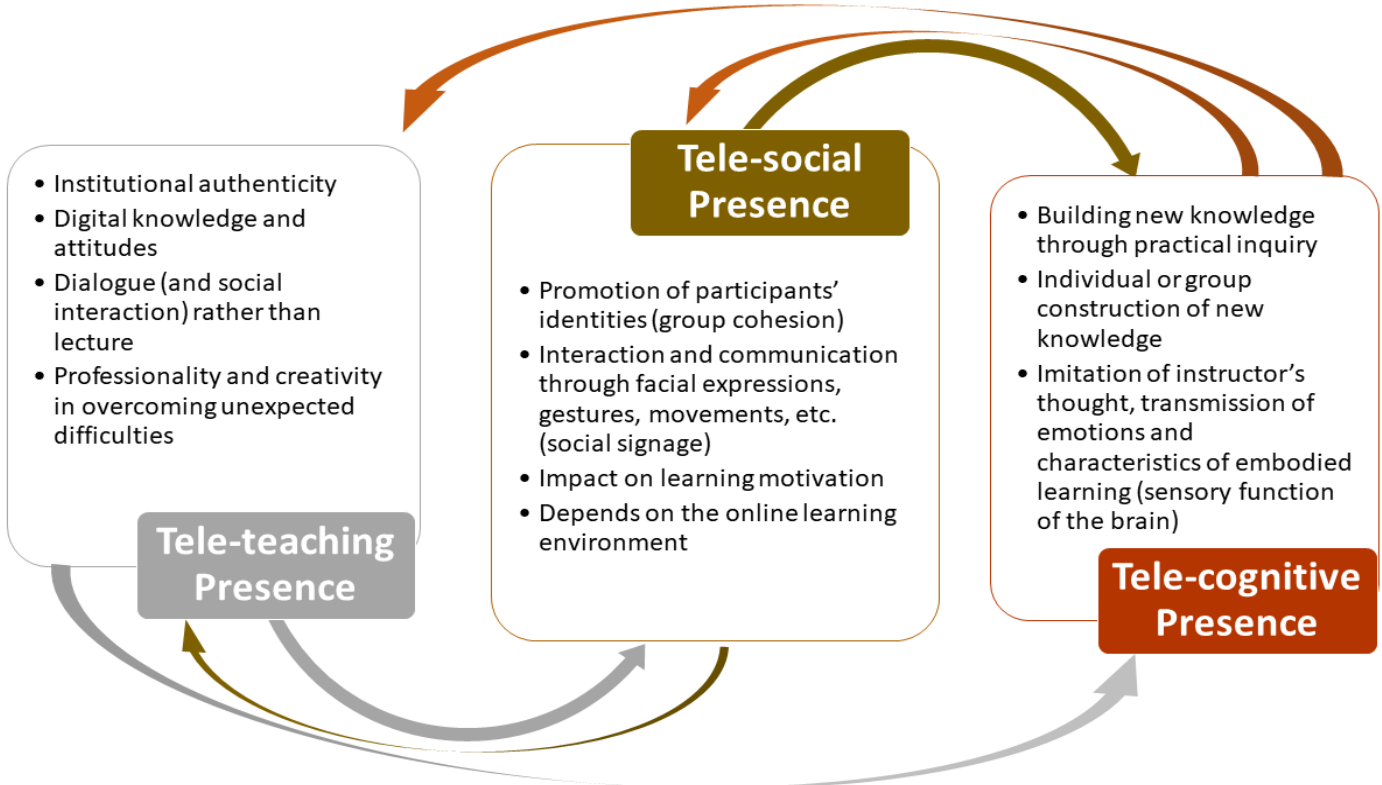

Figure 2. Characteristics of Tele-Community of Inquiry tele-presences

\section{The "embodied" learning}

The Theory of Tele-proximity reinforces the importance attributed to the role of the senses in learning, highlighting its embodied character. The importance of the senses in learning has preoccupied researchers since ancient times. According to Aristotle, sensory perception leads to learning as it interacts with the human's internal representations leading to new ones (Paivio, 2007; Papagiannidis, 2008; Fokas, 2013). Unlike Aristotle, Plato believed that learning stems only from 
the soul, through the pre-existing ideas that he reencounters in the material world (Fokas, 2013). Neuroscience nowadays by studying the brain, strengthens Plato's theory (Fokas, 2013).

Moreover, the ancient Greek philosophy dealt with the relationship between the senses and memory with the cognitive process triggered the development of modern cognitive theories, such as the Theory of Embodied Cognition (Lakoff, 2012; Wilson \& Foglia, 2016) (Figure 3). Embodied learning includes the interaction of the body with the natural environment through sensory-kinetic processes (Alibali \& Nathan, 2012; Iraklioti, Pantidos, \& Birbili, 2017; Kokkinidou, 2017). The participation of the body in learning can occur through social interaction, too (Kokkinidou, 2017). Besides the biological dimension of the body there is also the social one, through the body's expressions, manners, emotions and so on (Alexias, 2011).

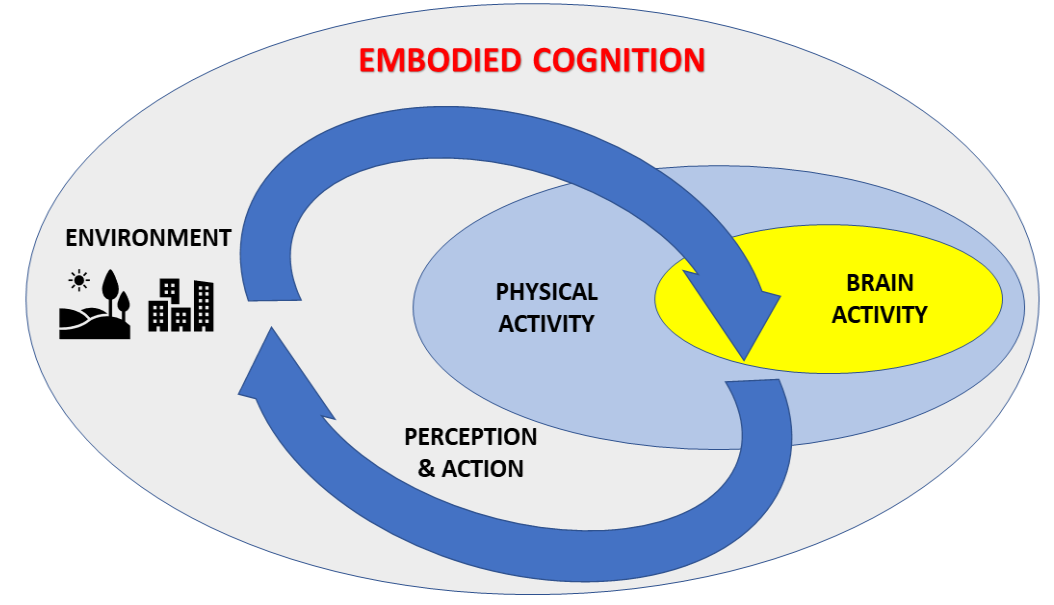

Figure 3. An Embodied Cognition Model. Adapted from Hinton (2014; Fig. 4-4)

Thus, the body is an agent as well as an expression in any social interaction (Alexias, 2011). Furthermore, the social dimension of the body cannot be separated from its biological (Alexias, 2011). Through sighting, in fact, it is possible to detect the meaning of the behaviour of others, hence visual perception has a dominant role in embodied learning (Iacoboni, 2009; Pentland, 2010; Wilson \& Foglia, 2016). Based on this, Illeris $(2009$; 2015; 2016) formulated the Theory of "Integrated" Learning. 


\section{The "integrated" learning}

The Theory of “Integrated" Learning (Illeris, 2009; 2015; 2016) (Figure 4) combines elements from cognitive and social learning theories.

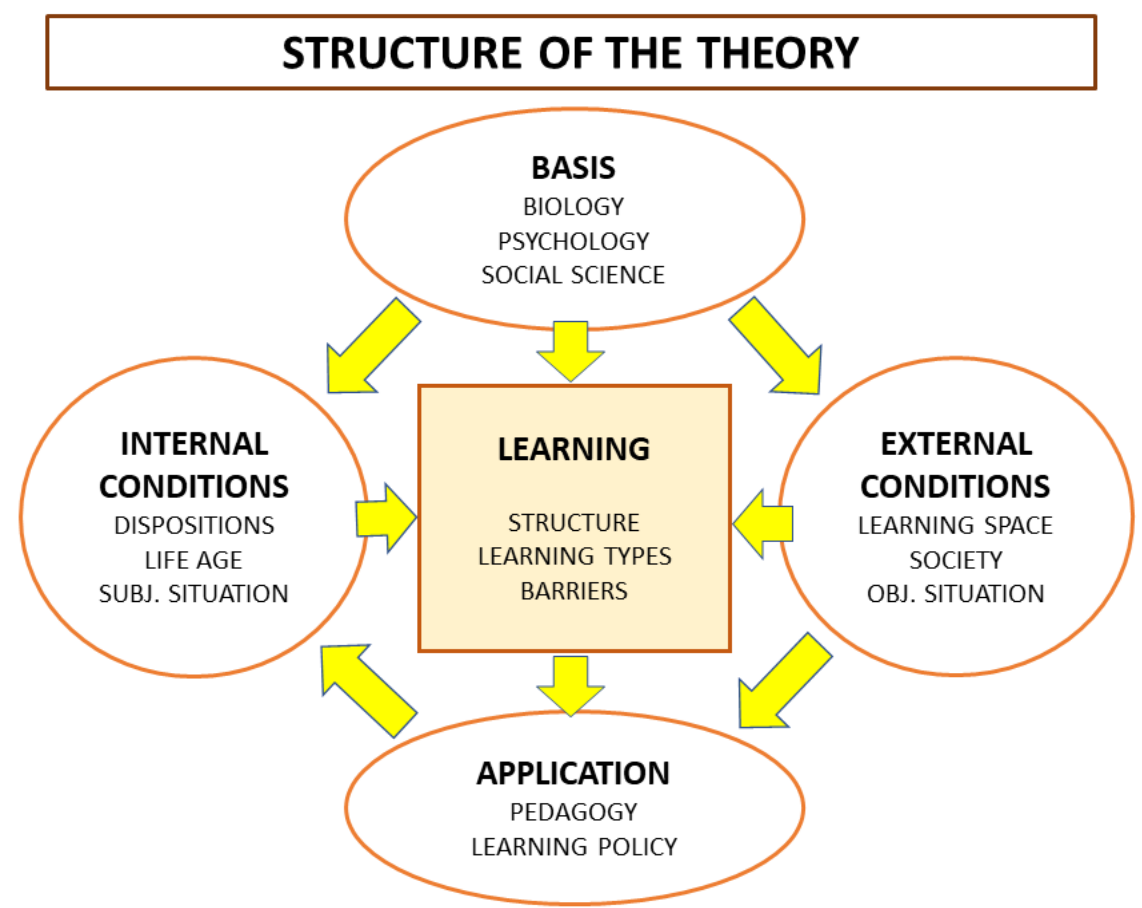

Figure 4. Theory of "Integrated" Learning. Adapted from Illeris (2009; p.8, Fig. 1.1)

In this learning model, knowledge is gained through the interaction of the individual with the environment, while it is noted that motivation, volition and emotion have an important role in the content of knowledge. Since content, motivation (internal and external) and environment (natural or social) are linked together in the learning process means that learning has cognitive, emotional and social characteristics. This is what Matteson (2014) named "integrated" learning (Figure 5). 


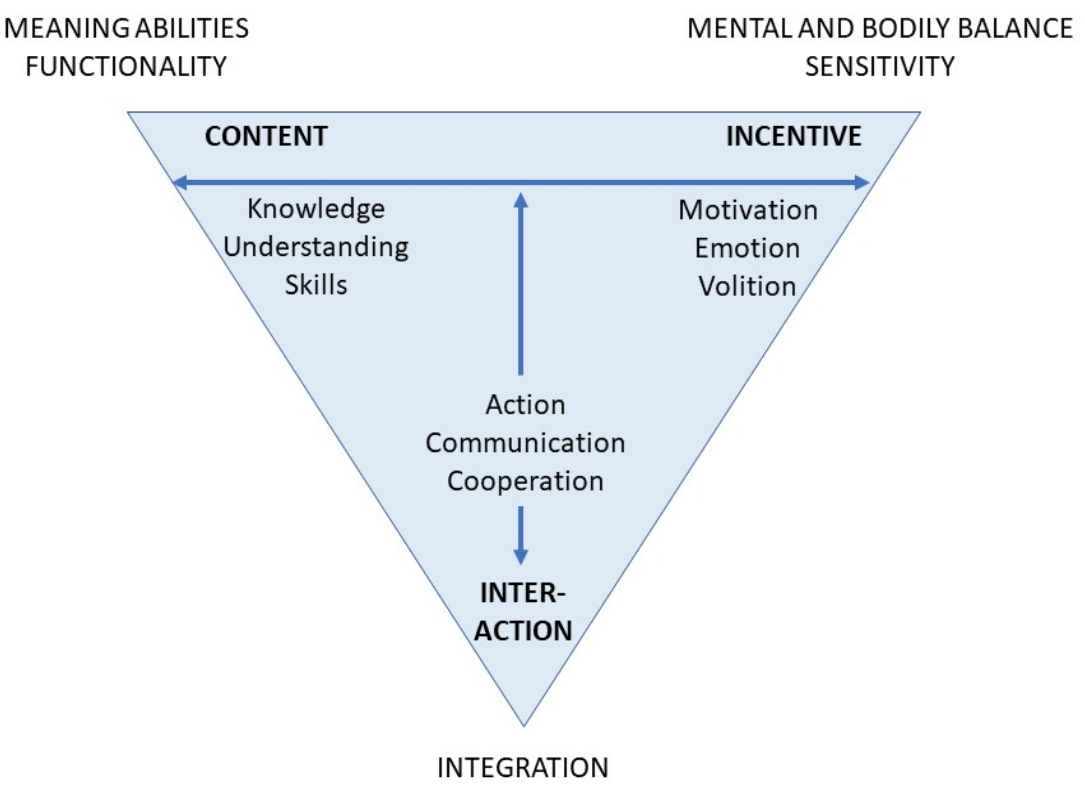

Figure 5. "Integrated" learning. Adapted from Illeris (2016; p.50, Fig, 3.3)

As it is defined by Neuroscience, in cognitive and emotional aspects of learning, the brain has the primary role. Research shows how motivation, personality traits and positive emotional attitude towards the content of knowledge increase the effectiveness of learning (Illeris, 2015; 2016; Matteson, 2014; Spencer \& Victor, 2017; Çaliskan, 2014). On the other hand, social factors have an important role in learning, through the cultivation of skills such as self-awareness, selfmanagement, collaboration, communication, group decision making, social awareness (Matteson, 2014). Although the Illeris' theory focused on conventional education, it can also be linked to learning in Distance Education. This is because effective learning in Distance education as such involves the learner's "integrated" cognitive, emotional, and practical activation (Lionarakis, 2006).

\section{The concept of Tele-mathesis in Distance Education}

The educational process through videoconferencing in Distance Education has similarities with the face-to-face teaching (Milioriitsas \& Georgiadi, 2010) because of the audiovisual "live" communication of the participants. In addition, the learning process is not differentiated in its essential mechanism, since this concerns the mental and interactive processes of human and not the educational method followed (Illeris, 2016; Kanellopoulos \& Koutsouba, 2017). However, it has specific characteristics due to the nature of the communication medium used (Kanellopoulos et al., 2020). Since the ancient Greek term "mathesis" emphasizes these specific characteristics, i.e. "embodied" and "integrated" learning, the concept "tele-mathesis" is proposed to this study to describe the learning process through videoconferencing. This is because "mathesis" can highlight the importance of perception and body in the learning process.

By applying Illeris' Theory of "Integrated" Learning $(2009 ; 2015 ; 2016)$ in the learning process through videoconferencing there seems to be analogies and similarities with the Theory of TeleProximity (Themeli \& Bougia, 2016; Themelis, 2014). More specifically, for Illeris (2009; 2015; 2016) learning has three dimensions: content, incentive, and interaction (Figure 6). 


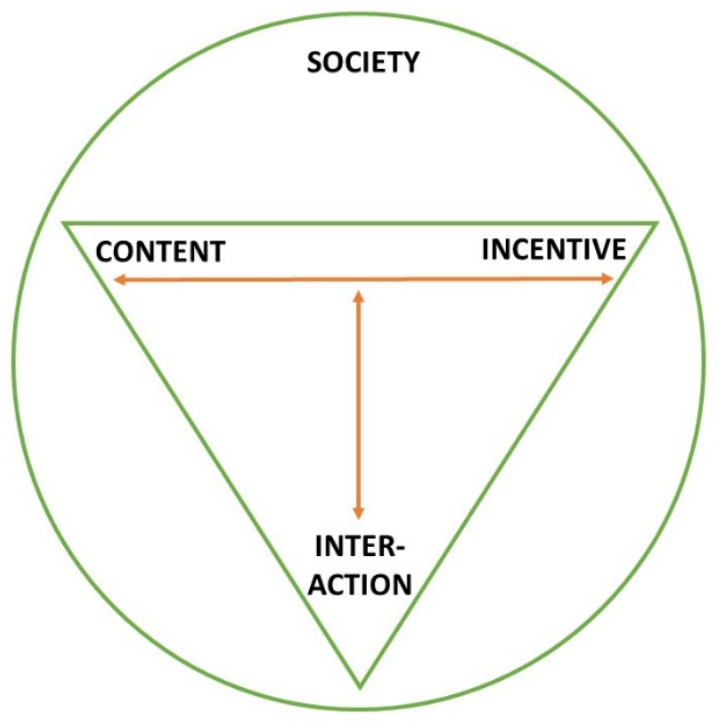

Figure 6. The dimensions of learning. Adapted from Illeris (2016; p.47, Fig. 3.2)

The content dimension corresponds to the tele-teaching presence that includes the actions for the design of the educational process and the organization and the selection of the content (i.e. knowledge, skills and attitudes) (Themeli \& Bougia, 2016; Themelis, 2014; Kanellopoulos, 2019; Kanellopoulos, Koutsouba, \& Giossos, 2019). The incentive dimension corresponds to the telecognitive presence, since the latter refers to the cognitive presence formed by the audiovisual messages of the videoconference (Kanellopoulos, 2019; Kanellopoulos et al., 2019). Finally, the interaction dimension is associated with the tele-social presence that characterises the social interaction of the participants and depends on the degree and the way of interaction with the electronic learning environment (Themeli \& Bougia, 2016; Themelis, 2014; Kanellopoulos, 2019; Kanellopoulos et al., 2019).

For Illeris $(2009 ; 2015 ; 2016)$, learning is also achieved through a two-way internal process, between content and incentive, which is in constant interaction with the learner's environment (Figure 7). Therefore, the three elements of this model seem to be interdependent and the acquisition of knowledge, or the learning effect, is their constituent. Likewise, the elements of the Tele-Proximity Theory are interdependent (Themeli \& Bougia, 2016; Themelis, 2014), since the formulation of a successful Tele-Community of Inquiry, that will lead to the acquisition of new knowledge, for this theory, arises from the harmonious and appropriate coexistence and interaction of tele-cognitive, tele-teaching and tele-social presence. 


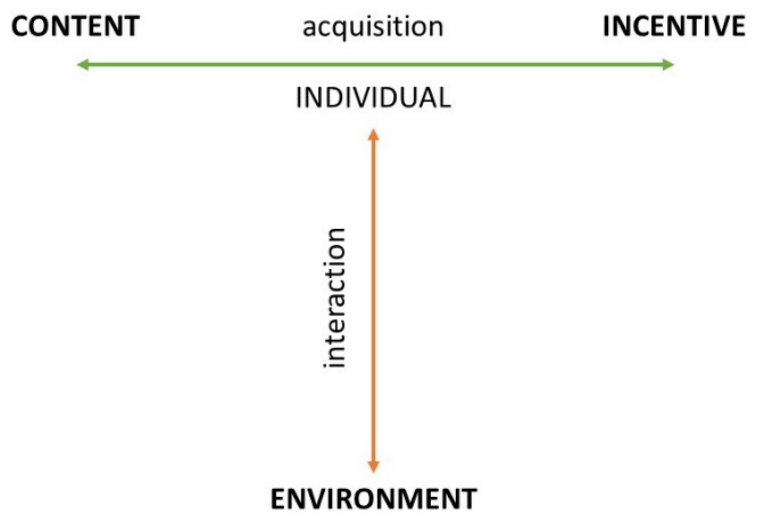

Figure 7. The processes of learning. Adapted from Illeris (2016, Fig. 3.1, p. 45)

Thus, the analogies between the two theories can lead to a new interpretation of the way of learning through videoconference, which stems from their composition (Kanellopoulos, 2019). The depiction of this synthesis is a new learning triangle (based on the Illeris' learning triangle) (Figure 8).

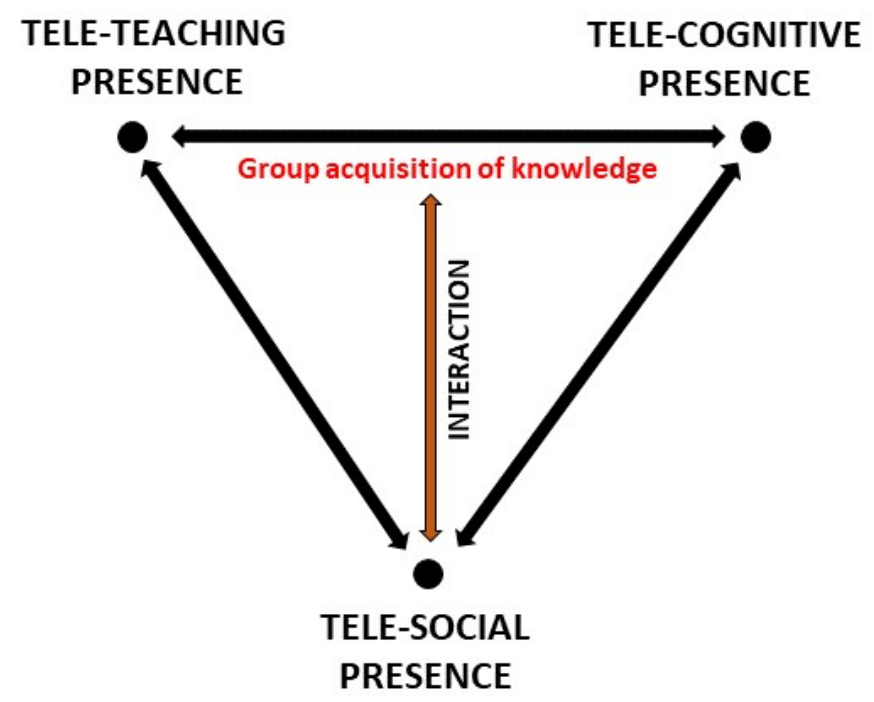

Figure 8. Tele-mathesis. Adapted from Kanellopoulos (2019, Fig. 6.4, p. 132)

In this new triangle of tele-mathesis the relations among the three tele-presences are depicted too (Kanellopoulos, 2019). The achievement of the learning outcome in the Tele-Community of Inquiry, through the construction of new knowledge with the use of the practical inquiry, is the result of a team process. This process determined by the tele-teaching presence that activates the tele-cognitive presence. This group process implies that individual process of acquiring knowledge is present too.

The activation, or not, of the tele-cognitive presence, based on the creation of the appropriate learning environment in the group, leads to the next stage of the educational process or to its redesign. The tele-teaching presence should be adapted, depending both on learners' bodies and faces' reactions as well as from their active participation or their verbal messages (Kanellopoulos, 2019). The audiovisual messages, along with those of the content itself (presentation software or 
other educational applications) determine the tele-social and the tele-cognitive presence (Kanellopoulos, 2019).

Tele-mathesis is based on the sensory perception that is essential for the formulation of the three basic elements of tele-mathesis (tele-cognitive, tele-teaching and tele-social presence) and for the dynamic relationship that develops among them (Kanellopoulos, 2019). The perception concerns either the audiovisual representation of the content (presentation software and the tutor) or the social interaction that takes place in videoconference. Tele-mathesis also relies on the expressions of participants' faces (and movements) (Kanellopoulos, 2019) that are part of the so-called "techniques of the body" (Alexias, 2011).

After all, the visual perception is created not only by simple transfer of visual stimuli to the brain, but also through the creation of conceptual metaphors with expressions (or movements) of the body that can take effect autonomously or in combination with the verbal speech and strengthen (or inhibit) the learning outcome (Lakoff, 2012; Iraklioti et al., 2017). Essentially, through vision, the meaning of the behaviour of other people is detected (Iacoboni, 2009; Pentland, 2010; Wilson \& Foglia, 2016), which influences social interaction, which in turn influences the learning outcome through the cultivation of a positive or negative learning environment. Thus, the visual perception contributes to the cultivation of immediacy and intimacy that lead to the reduction of the transactional distance (Themeli \& Bougia, 2016) and the development of perceptual learning (Tsoukaki, 2015).

From the above, it seems that tele-mathesis has an "embodied" character (Figure 9) as the role of the body is decisive (Kanellopoulos, 2019). In fact, tele-mathesis includes a physical and mental aspect as the Illeris' theory supports (Illeris, 2009; 2015; 2016) for learning in general, as well as the coexistence and interaction of the body with the mind (Alexias, 2011).

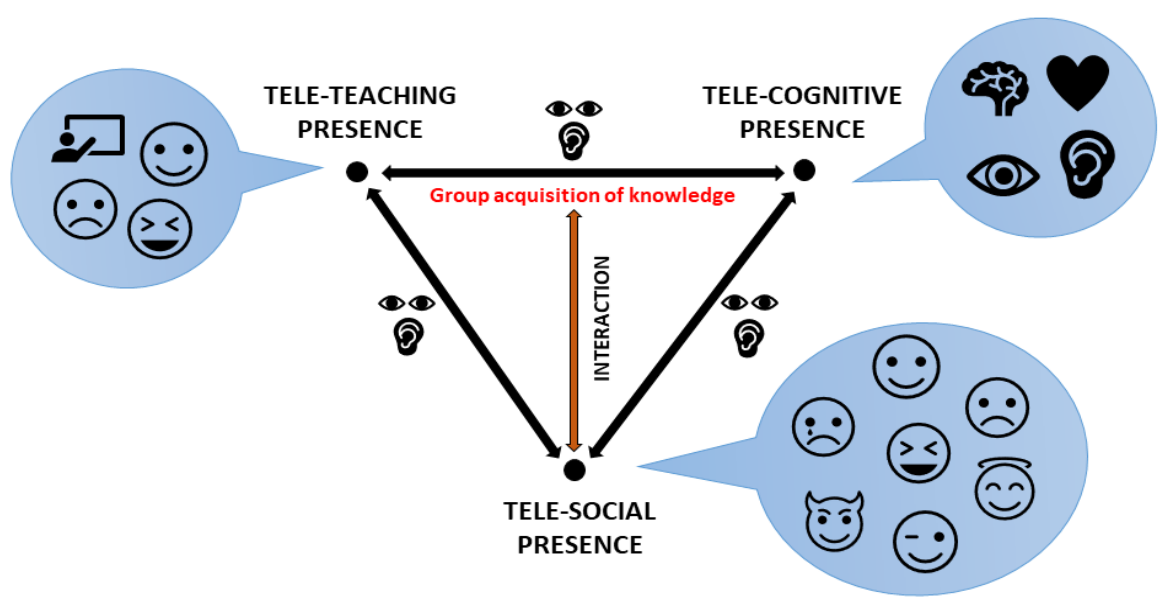

Figure 9. The embodied tele-mathesis

However, tele-mathesis takes, also, on the character of "integrated" learning according to the Illeris' theory $(2009 ; 2015 ; 2016)$ since it is defined and includes cognitive, emotional and social factors (Kanellopoulos, 2019). When these factors are activated, the result is the integration of the learner in the learning community and the wider society (Illeris, 2009) (Figure 10). 


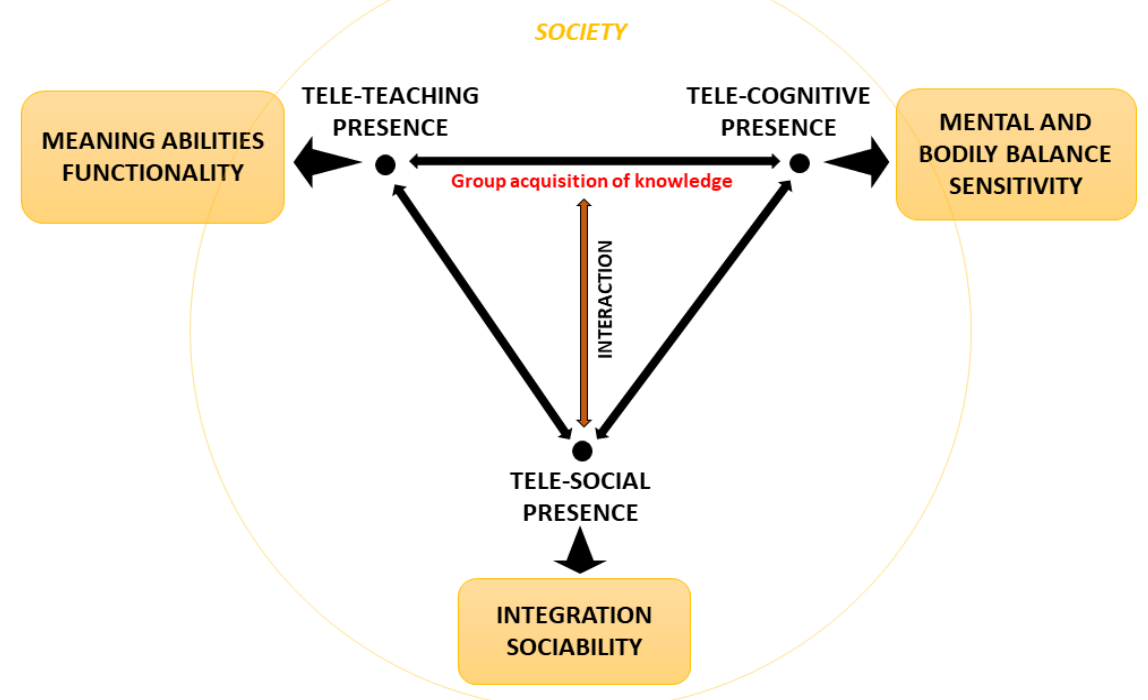

Figure 10. The "integrated" tele-mathesis

\section{Conclusions}

In this study, the aim was to propose the introduction of the concept tele-mathesis in Distance Learning, in order to describe the learning process by videoconferencing in Distance Education, which has features of an "embodied" and "integrated" way of learning. It is a theoretical study based on Illeris' Theory of "Integrated" Learning that has been adopted in Distance Learning, using elements of the Theory of Tele-proximity concerning learning by videoconferencing in Distance Education. According to the developed argumentation, the importance of the senses, emotions and "techniques of the body" is revealed in both the educational and learning process by videoconferencing, in order to reduce the transactional distance between the teacher and the learner, as well as, to lead to a positive distance educational experience. Thus, the cognitive, emotional and social factors involved in "tele-mathesis", turn videoconferencing into an "embodied" and "integrated" way of learning. At the same time, it is showed that the empowerment of "tele-mathesis" requires appropriate planning and specific management methods. It is therefore proposed to introduce the term tele-mathesis in Distance Education so as to fully attribute this specific learning process of Distance Education.

In particular, in tele-mathesis, the learning process occurs with the dynamic interaction of the Theory of Tele-proximity's three-dimensional presences, that tele-cognitive, tele-teaching and telesocial presence. The tele-cognitive presence is affected and affects the tele-teaching presence. The teacher must focus on audiovisual messages (verbal and non-verbal) that are transmitted to the learners along with the messages transmitted by the "techniques of the body", and vice-versa. This focus functions as feedback and contributes to the formulation of a positive learning environment. The tele-social presence is characterized by social interaction and it is associated both with teleteaching and tele-cognitive presence. Audiovisual messages transmitted by the "techniques" of the participants' bodies, determine the degree of tele-social presence contributing in educational and learning process. 
In conclusion, tele-mathesis as a concept refers to an "embodied" and "integrated" way of learning in the environment of videoconferencing. It reinforces the necessity of proper and specific design of the videoconference educational process that ought to be based on pedagogical criteria so as to enhance the quality of both learning and teaching (Themeli \& Bougia, 2016; Wu et al., 2013; Lionarakis et al., 2018).

This study, as any study, has its limitations. The main one is its theoretical nature. Thus, empirical research has to follow. Further research is required on the relation of the emotions of the tutors, and/or the learners, which are developed during the educational process. A very interesting issue for empirical study, also, is the role of the body (tutor and learners) in the educational process through videoconferencing. Finally, since the aim in Distance Education is to develop communities of inquiry, it is worth considering whether in the videoconferences the learners operate within such a community.

\section{References}

1. Alexias, G. (2011). Sociology of the Body. Athens: Pedio.

2. Alibali, M. W., \& Nathan, M. J. (2012). Embodiment in Mathematics Teaching and Learning: Evidence From Learners' and Teachers' Gestures. Journal of the Learning Sciences, 21(2), 247286. doi:10.1080/10508406.2011.611446

3. Anastasiadis, P., Manousou, E., Filippousis, G., Siakas, S., Koukoulis, N., Tomazinakis, A., ..., \& Karvounis, L. (2009). Videoconference and collaborative knowledge construction. From Theory to Practice: "ODYSSEUS 2009: Environment - Mediterranean Sea "KAPETAN SOS" Energy revolution - Renewable Energy”. In A. Lionarakis (Ed.), $5^{\text {th }}$ International Conference in Open \& Distance Learning. Open \& Distance Learning for Global Collaboration and Educational Development. Athens November 27 $7^{\text {th }} 29^{\text {th }} 2009$ (pp. 111-124). http://dx.doi.org/10.12681/icodl.503

4. Anastasiadis, P., Manousou, E., Siakas, S., Filippousis, G., Koukoulis, N., Tomazinakis, A., ..., \& Karvounis, L. (2011). Videoconference and collaborative knowledge construction. From Theory to Practice: "ODYSSEUS 2011: Environment - Mediterranean Sea "KAPETAN SOS" Energy revolution - Renewable Energy”. In A. Lionarakis (Ed.), $6^{\text {th }}$ International Conference in Open \& Distance Learning. Alternative Forms of Education. Loutraki November $4^{\text {th }}-6^{\text {th }} 2011$ (pp. 669-684). http://dx.doi.org/10.12681/icodl.685

5. Armakolas, S., \& Panagiotakopoulos, C. (2020). Distance learning through videoconferencing: the effects of technological factors. Open Education - The Journal for Open and Distance Educational Technology, 16(1), 22-43. https://doi.org/10.12681/jode.22800

6. Çaliskan, M. (2014). Effect of Cognitive Entry Behaviors and Affective Entry Characteristics on Learning Level. Educational Sciences: Theory and Practice, 14(5), 1816-1821. Retrieved December 30, 2018, from https://eric.ed.gov/?id=EJ1050556 
7. Fokas, A. S. (2013, January). Knowledge: from Antiquity to Today. Announcement in the Feast of Letters, University of Cyprus, Nicosia. Retrieved January 26, 2019, from https://www.ucy.ac.cy/pr/documents/\%CE\%91rticles_speeches/2013/Athanasios_Foka.pdf

8. Garrison, D. R., Anderson, T., \& Archer, W. (1999). Critical Inquiry in a Text-Based Environment: Computer Conferencing in Higher Education. The Internet and Higher Education, 2(2-3), 87-105. doi:10.1016/S1096-7516(00)00016-6

9. Gkousios, C., \& Tzanavari, M. (2009). Implementations of videoconferencing technologies in the pedagogical process of language learning. In A. Lionarakis (Ed.), $5^{\text {th }}$ International Conference in Open \& Distance Learning. Open \& Distance Learning for Global Collaboration and Educational Development. Athens November $27^{\text {th }}-29^{\text {th }} 2009$ (pp. 280-328). http://dx.doi.org/10.12681/icodl.498

10. Hillman, D. C. A., Willis, D. J., \& Gunawardena, C. N. (1994). Learner-interface interaction in distance education: An extension of contemporary models and strategies for practitioners. American Journal of Distance Education, 8(2), 30-42. doi:10.1080/08923649409526853

11. Hinton, A. (2014). Understanding Context [eBook version]. Retrieved May 18, 2019, from https://www.oreilly.com/library/view/understanding-context/9781449326531/ch04.html

12. Iacoboni, M. (2009). Imitation, Empathy, and Mirror Neurons. Annual Review of Psychology, 60(1), 653-670. doi:10.1146/annurev.psych.60.110707.163604

13. Illeris, K. (2009). A comprehensive understanding of human learning. In K. Illeris (Ed.), Contemporary theories of learning: Learning theorists...in their own words (pp. 7-20). New York: Routledge.

14. Illeris, K. (2015). The Development of a Comprehensive and Coherent Theory of Learning. European Journal of Education, 50(1), 29-40. doi:10.1111/ejed.12103

15. Illeris, K. (2016). The way we learn. The multiple dimensions of learning in formal and informal education. Athens: Metehmio.

16. Iraklioti, E., Pantidos, P., \& Birbili, M. (2017). The human body as a means of transferring knowledge: application for the shadow effect to pre-school children. In D. Stavrou, A. Mihailidi \& A. Kokolaki (Eds.), $10^{\text {th }}$ Hellenic Conference of Didactics of Science and New Technologies in Education. "Bridging the Gap between Sciences, Society and Educational Act". Rethymno, April $7^{\text {th }}-9^{\text {th }} 2017$ (pp. 223-229). Retrieved January 7, 2020, from http://synedrio2017.enephet.gr/images/Praktika-10ou-Synedriou_Teliko.pdf

17. Jézégou, A. (2010). Community of Inquiry in E-learning: A Critical Analysis of the Garrison and Anderson Model. International Journal of E-Learning \& Distance Education, 24(3). Retrieved December 8, 2018, from http://www.ijede.ca/index.php/jde/article/view/707

18. Kanellopoulos, A. (2019). Videoconferencing in Distance Education as an embodied and "integrated" way of learning. Towards a new theoretical framework of "tele-mathesis". (Unpublished Master Thesis). Hellenic Open University, Patras. Retrieved November 30, 2019 from https://apothesis.eap.gr/handle/repo/44987 
19. Kanellopoulos, A., \& Koutsouba, M. (2017). Connecting Practices of Open and Distance Education, New Technologies and Forms of Learning. The case of MOOCs. In A. Lionarakis, S. Ioakimidou, M. Niari, G. Manousou, T. Hartofylaka, S. Papadimitriou \& A. Apostolidou (Eds.), $9^{\text {th }}$ International Conference in Open \& Distance Learning. The Design of Learning. Athens November $23^{\text {rd }}-26^{\text {th }} 2017$ (pp. 123-135). http://dx.doi.org/10.12681/icodl.1128

20. Kanellopoulos, A., \& Koutsouba, M. (2019). The Research on Videoconferencing in Distance Education. A Bibliographical Review. Open Education - The Journal for Open and Distance Educational Technology, 15(2), 54-77. http://dx.doi.org/10.12681/jode.21619

21. Kanellopoulos, A., Koutsouba, M., \& Giossos, Y. (2019). Learning on a Tele-community of Inquiry. From the Transactional Distance Theory to the Theory of Tele-proximity. In A. Lionarakis, G. Manousou, S. Ioakimidou, M. Niari, A. Angeli, K. Sfakiotaki \& V. Koutzeklidou (Eds.), $10^{\text {th }}$ International Conference in Open \& Distance Learning. The Design of Learning. Athens November $22^{\text {nd }}-24^{\text {th }} 2019$ (pp. 170-183). http://dx.doi.org/10.12681/icodl.2329

22. Kanellopoulos, A., Koutsouba, M., \& Giossos, Y. (2020). Audiovisual Learning and Videoconferencing in Distance Education. Open Education - The Journal for Open and Distance Educational Technology, 16(1), 44-63. https://doi.org/10.12681/jode.22976

23. Kokkinidou, A. (2017). Study, design and development of an interactive surface for maths practicing with simultaneous physical activity stimulation. (Unpublished Master Thesis). Hellenic Open University, Patras. Retrieved January 5, 2019 from https://apothesis.eap.gr/handle/repo/33903

24. Lionarakis, A. (2006). The theory of Open and Distance Learning and the complexity of its polymorphic dimension. In A. Lionarakis (Ed.), Open and Distance Learning - Elements of theory and act (pp. 11-41). Athens: Propompos.

25. Lionarakis, A., Papadimitriou, S., Hartofylaka, A., Aggeli, A., \& Tzilou, G. (2018). The contribution of digital tools to students' support in distance learning environments: Part A. The use of digital tools for the creation of digital learning material. Open Education - The Journal for Open and Distance Educational Technology, 14(1), 104-117. http://dx.doi.org/10.12681/jode.18533

26. Lachman, S. J. (1997). Learning is a Process: Toward an Improved Definition of Learning. The Journal of Psychology, 131(5), 477-480. doi:10.1080/00223989709603535

27. Lakoff, G. (2012). Explaining Embodied Cognition Results. Topics in Cognitive Science, 4(4), 773-785. doi:10.1111/j.1756-8765.2012.01222.x

28. Milioritsas, E., \& Georgiadi, E. (2010). The influence of videoconference in the Hellenic Open University's learning process. Aspects of students and tutors from distance learning and adult learning subject modules. Open Education - The Journal for Open and Distance Educational Technology, 6(1-2), 152-167. http://dx.doi.org/10.12681/jode.9757 
29. Matteson, M. L. (2014). The Whole Student: Cognition, Emotion, and Information Literacy. College \& Research Libraries, 75(6), 862-877. doi:10.5860/crl.75.6.862

30. Mavroidis, I., Karatrantou, A., Koutsouba, M., Giossos, Y., \& Papadakis, S. (2013). Technology Acceptance and Social Presence in Distance Education-A Case Study on the Use of Teleconference at a Postgraduate Course of the Hellenic Open University. European Journal of Open, Distance and e-Learning, 16(2), 76-96. Retrieved November 26, 2020, from https://old.eurodl.org/materials/contrib/2013/Mavroidis_et_al.pdf

31. Moore, M. G. (1989). Editorial: Three types of interaction. American Journal of Distance Education, 3(2), 1-7. doi:10.1080/08923648909526659

32. Moore, M. G. (1993). Theory of transactional distance. In D. Keegan (Ed.), Theoretical Principles of Distance Education (pp. 22-38). New York: Routledge.

33. Paivio, A. (2007). Mind and Its Evolution: A Dual Coding Theoritical Approach. New York: Psychology Press.

34. Panagiotakopoulos, C., Tsiatsos, T., Lionarakis, A., \& Tzanakos, N. (2013). Teleconference in support at distance learning: Views of educators. Open Education - The Journal for Open and Distance Educational Technology, 9(1), 5-18. http://dx.doi.org/10.12681/jode.9806

35. Papagiannidis, G. (2008). Senses and the common sense in Aristotle. (Unpublished Master Thesis). Aristotle University of Thessaloniki, Thessaloniki. Retrieved January 26, 2019, from http://ikee.lib.auth.gr/record/109650

36. Pentland, A. (2010). Defend Your Research: We Can Measure the Power of Charisma. Harvard Business Review. Retrieved December 15, 2018, from https://hbr.org/2010/01/defend-your-research-we-can-measure-the-power-of-charisma

37. Pentland, A. (2012). The New Science of Building Great Teams. Harvard Business Review. Retrieved December 15, 2018, from https://hbr.org/2012/04/the-new-science-of-buildinggreat-teams

38. Rogers, A. (1999). Adult Education. Athens: Metehmio.

39. Schunk, D. H. (2012). Learning Theories: An Educational Perspective (6 ${ }^{\text {th }}$ ed.). Boston: Pearson.

40. Sime, J. A., \& Themelis, C. (2018). Exploring Video Literacy and the Practice of Educators: Videos, Vlogs, Videoconferencing and Holographic Teleportation. In T. Bastiaens, J. Van Braak, M. Brown, L. Cantoni, M. Castro, R. Christensen, G. Davidson-Shivers, K. DePryck, M. Ebner, M. Fominykh, C. Fulford, S. Hatzipanagos, G. Knezek, K. Kreijns, G. Marks, E. Sointu, E. Korsgaard Sorensen, J. Viteli, J. Voogt, P. Weber, E. Weippl, \& O. Zawacki-Richter (Eds.), edMedia \& Innovate Learning World conference on educational Media and Technology. June $25^{\text {th }}-29^{\text {th }}, 2018$ (pp. 2029-2036). Netherlands: Association for the Advancement of Computing in Education (AACE). Retrieved December 15, 2018, from https://www.learntechlib.org/p/184444/

41. Spencer, T., \& Victor, S. (2017). Transforming Learning: Using Video for Cognitive, Emotional, and Social Engagement. Retrieved December 12, 2018, from 
https://www.researchgate.net/publication/315111260_Transforming_Learning_Using_Video _for_Cognitive_Emotional_and_Social_Engagement

42. Tsoukaki, E. (2015). Molecular Base of Human Brain Memory. (Unpublished Master Thesis). Hellenic Open University, Patras. Retrieved January 7, 2019 from https://apothesis.eap.gr/handle/repo/30245

43. Themeli, C., \& Bougia, A. (2016). Tele-proximity: Tele-community of Inquiry Model. Facial Cues for Social, Cognitive, and Teacher Presence in Distance Education. The International Review of Research in Open and Distributed Learning, 17(6), 145-163. Retrieved November 6, 2018, from http://www.irrodl.org/index.php/irrodl/article/view/2453/3950

44. Themelis, C. (2014). Synchronous Video Communication for Distance Education: the educators' perspective. Open Praxis, 6(3), 245-256. doi:10.5944/openpraxis.6.3.128

45. Wilson, R. A., \& Foglia, L. (2016). Embodied Cognition. In E. N. Zalta (Ed.), The Stanford encyclopedia of philosophy (Winter 2016 Edition). Retrieved January 5, 2019, from https://plato.stanford.edu/archives/win2016/entries/embodied-cognition/

46. Wu, E., Lin, W.-C., \& Yang, S. C. (2013). An experimental study of cyber face-to-face vs. cyber text-based English tutorial programs for low-achieving university students. Computers \& Education, 63, 52-61. doi:10.1016/J.COMPEDU.2012.11.018

47. Xin, C. (2012). A Critique of the Community of Inquiry Framework. International Journal of E-Learning \& Distance Education, 26(1). Retrieved December 8, 2018, from http://www.ijede.ca/index.php/jde/article/view/755 